\title{
EFFORTS TO CONSERVE ENDANGERED TERRESTRIAL ORCHIDS IN SITU AND EX SITU AT TWO NATURAL RESERVES WITHIN CENTRAL MEXICO
}

\author{
Monica Rangel-Villafranco ${ }^{1} \&$ M. Pilar Ortega-LarroceA ${ }^{1,2}$ \\ 'Departamento de Edafología, Instituto de Geología, Universidad Nacional Autónoma de México. Circuito \\ Exterior de Ciudad Universitaria, México Distrito Federal, 04510. México. \\ ${ }^{2}$ Author for correspondence: mpol@geologia.unam.mx
}

KEY WoRDS: in situ conservation, ex situ conservation, orchid fungi isolation, seed banks

The natural vegetation in and around Mexico City once harbored an unusually high number of plant and animal (insect) species, including endemics (Vázquez 1973, Ceballos \& Galindo 1984, Rzedowski 1991). The high diversity in this region has been attributed to the unusual topography resulting from a series of volcanic eruptions that ended $c a .1800$ years ago (Siebe et al. 2004). In addition, two phyto-geographic regions overlap within Central Mexico that support diverse vegetation types (e.g., shrubs, mature pine forests). Due to the rapid, uncontrolled growth of Mexico City's population, and surrounded Cities as Cuernavaca, many of these habitats have been destroyed, prompting the establishment of several natural reserves, especially south of the city. Two reserves are the subject of this study: El Pedregal in Mexico City, and El Corredor Biológico AjuscoChichinautzin limited by the southern Mexico City and Northern Morelos State. El Pedregal is a relictual area (237 ha) where some representative elements of the original fauna and flora of this Valley still prevail (Valiente-Banuet \& De Luna-García 1994, Téllez 2002, Castillo-Argüero et al. 2004, Hágsater et al. 2005). A xerophytic shrub vegetation is supported by a basaltic shield where any developed soil can be found other than organic matter accumulations in depressions and fissures (Cano-Santana \& Meave 1996). High plant diversity was described initially by Rzedowsky (1954) (c.a. 350 species) and Asteraceae, Poaceae, Leguminoseae and Orchidaceae Families are the dominant (Herrera \& Almeida 1994). Terrestrial orchid diversity has been documented, especially in El Pedregal and a total of 25 orchid species have been reported, including five species on the verge of extinction (Bletia punctata, Cyrtopodium macrobulon, Epidendrum anisatu, Habenaria strictissima, Liparis greenwoodiana) (Hágsater et al. 2005).

In contrast, in the Chichinautzin Area, eight types of vegetation can be found. An altitudinal gradient joint with successive periods of volcanic activity are combined and pedogenetic processes through time and parental material result in a chronosequence of soils. Main vegetation type is Pinus forest developed in elevations from 1800 to $3500 \mathrm{~m}$ and in an extension of 65, 700 ha. Around 785 different plant species have been described where Orchidaceae is the more diverse Family with 125 species (six are protected and 25 are listed in the IUCN-CITES and the Red List of Threatened Plants (Espejo et al. 2000).

The main ecological problem in the first place is the habitat fragmentation where the degradation processes are the spread of non-controlled fires during the dry season, over collection and pollution problems, such as trash dumps replacing native for perturbed flora. Meanwhile at the second place, the main degradation processes are the conversion of forest into agricultural lands as a result of overpopulation, with subsequent irrational exploitation of wood and also uncontrolled fires. In both habitats, the Orchidaceae is one of the most endangered families because of the changes in vegetation, soil use and over collection that do not allow populations to recover (Rubluo et al. 1993, Mera et al. 2002, Téllez 2002, Koopowitz et al. 2003, Wotavová et al. 2004). This problem gets worse from the fact that no governmental effort is made to preserve biodiversity in seed collections as has been done for some forest species. In consequence, there is not any future perspective to consider soil microorgan- 
isms as mycorrhizal fungi in conservation strategies like habitat restoration, for this particular group (Zettler 1997). On the other hand, it is well supported and established the use of ectomycorrhizal fungi in reforestation of gymnosperm forest with macromycetes. The main problem is that local inoculation programs do not use native fungi and when done, they do it with commercial isolates.

We have conducted an extensive project aimed at monitoring, conserving germoplasma, and isolating mycorrhizal fungi from orchids at both sites. Our aim is not to begin an uncontrolled seed collection practice without the isolation of associated mycorrhizal fungi in order to promote symbiotic germination with natural isolates. Studies at El Pedregal initiated in 2002 during the rainy season and we were able to found half of the original described orquiflora for this habitat. We started a germless storage with a total of 105 capsules and 73 different collect numbers with 38 identified isolates at the anamorphic stage (Currah et al. 1997). Some examples are shown in Table 1, Fig. 1.

At the second place, El Corredor Chichinautzin, because of its big extension, we started to locate well conserved forest sites with contrasting soil quality. Recently (2005) we identified a total of 25 species in sites with non-developed soils similar to the El Pedregal habitat and sites with deep and well developed Andosols. In one year of field monitoring during the rainy season, we got 250 capsules ( 65 collected numbers) and 18 mycorrhizal isolates, all of them nearly identified in the anamorph stage (Table 1, Figs. 1 and 2). One of this unidentified isolates belonged to an achlorphylic orchid Corallorhiza maculata.

A variety of morphological features were found in the different isolates as well as specificity for the plant species with their mycorrhizal fungi. There is less morphological variation between the isolates found in El Pedregal probably due to the fact that they come from fewer species of orchids in a smaller habitat. A wide morphological variation was detected in the isolates from the Chichinautzin, also because they come from more orchid species and habitats. Main morphological variations are related to the rate of development and the texture of the mycelium forming the colony in the Petri dish. Epulorhiza spp. isolates have consistently waxy mycelium with sub- merged hyphae in yellowish- pale brown colors where monilioid cells are quite similar. Molecular studies have been conducted for the isolates from El Pedregal and all teleomorphic species of Epulorhiza belong to Tulsnellaceae, particularly Tullasnella calospora (Rangel 2006). For Ceratorhiza spp., a less specific determination was obtained to the Family Ceratobasidae. Morphological features of Epulorhiza spp. isolates from Corredor Chichinautzin are more cottony-texture with aerial mycelium, white and sometimes similar to Ceratorhiza colonies (Fig. 2B, $\mathrm{O}$ and R). Instead, few Ceratorhiza cultures grew as Epulorrhiza, without concentric rings and waxy texture (Fig. 1Y). Ceratorhiza cultures grew faster but some moniliod cells developed more slowly in some cultures and it was difficult to appreciate them because they don not finish in clumps as Epulorhiza (Fig. 1E1, Fig. 2H).

Although this is a preliminary study for the mycorrhizal fungi diversity associated to terrestrial orchids in southern Mexico City, we have a very clear picture of the morphological diversity that can be found associated to plant species. It looks like some genera are highly specific for their mycobiont as the couples Bletia - Epulorhiza, Dichromanthus - Ceratorhiza, Habenaria - Epulorhiza, and Malaxis - Epulorhiza. More evidence is required to confirm whether this specificity always occurs in nature, due to the fact that some symbiotic cultures can be developed in vitro with different isolates (Rangel 2004). Bioassays confirm specificity at some level; we have noticed that Bletia species are less specific for both genus isolates than Dichromanthus. However, results for the in vitro propagation must be interpreted carefully and do not reflect the specificity in nature. In situ bioassays demonstrate that specificity can be developed through the life history of the plant (Rangel 2006). The Bletia spp. can be probably less dependent on fungi for in vitro germination and less specific because they photosynthesize rapidly; but in nature, populations are more endangered than Dichromantthus and seedlings are very difficult to observe where asexual corm propagation is common (Ortega-Larrocea and Rangel, same volume). The Ceratorhiza fungi grew faster in vitro, but we do not know whether the same behavior found in 


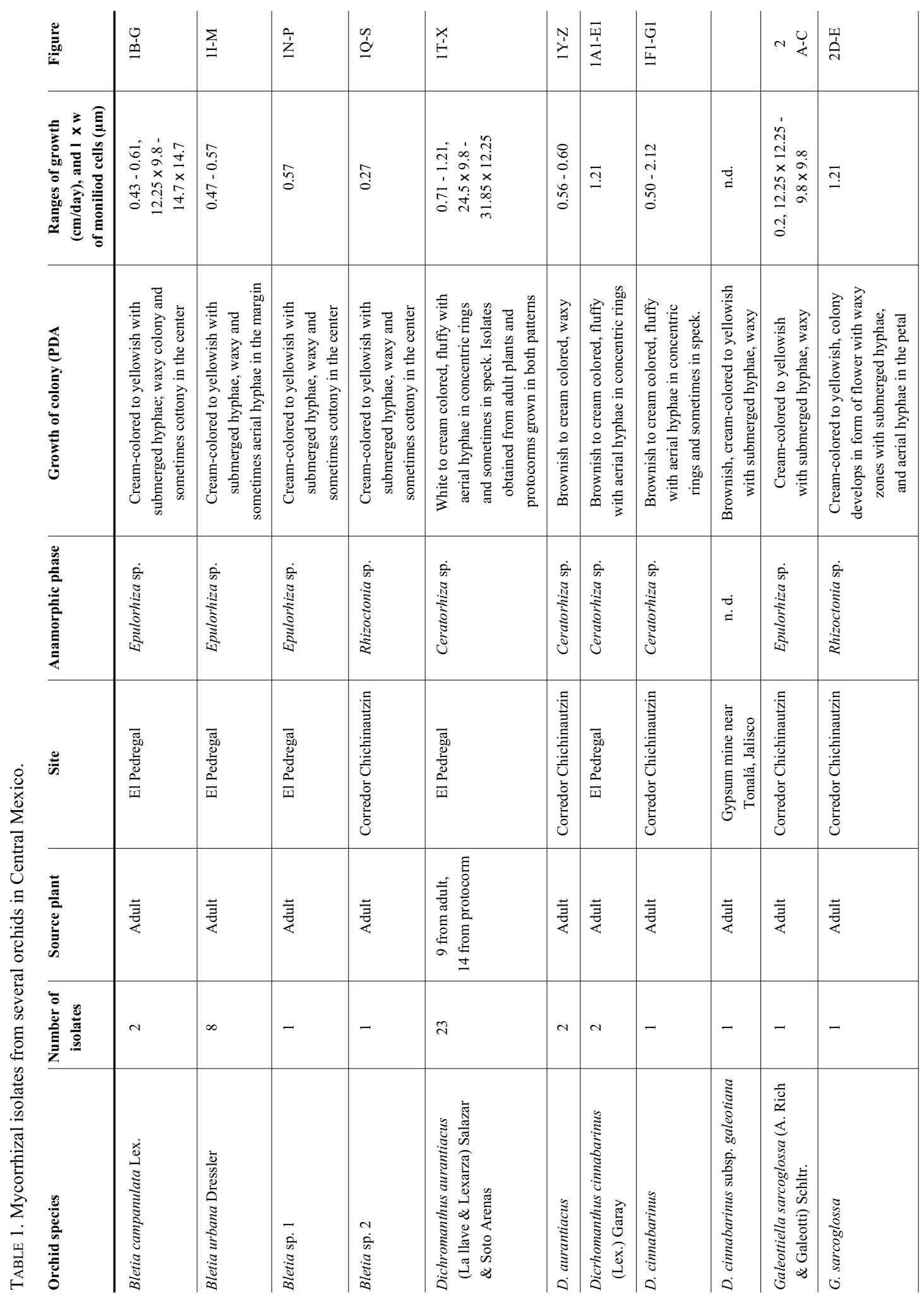




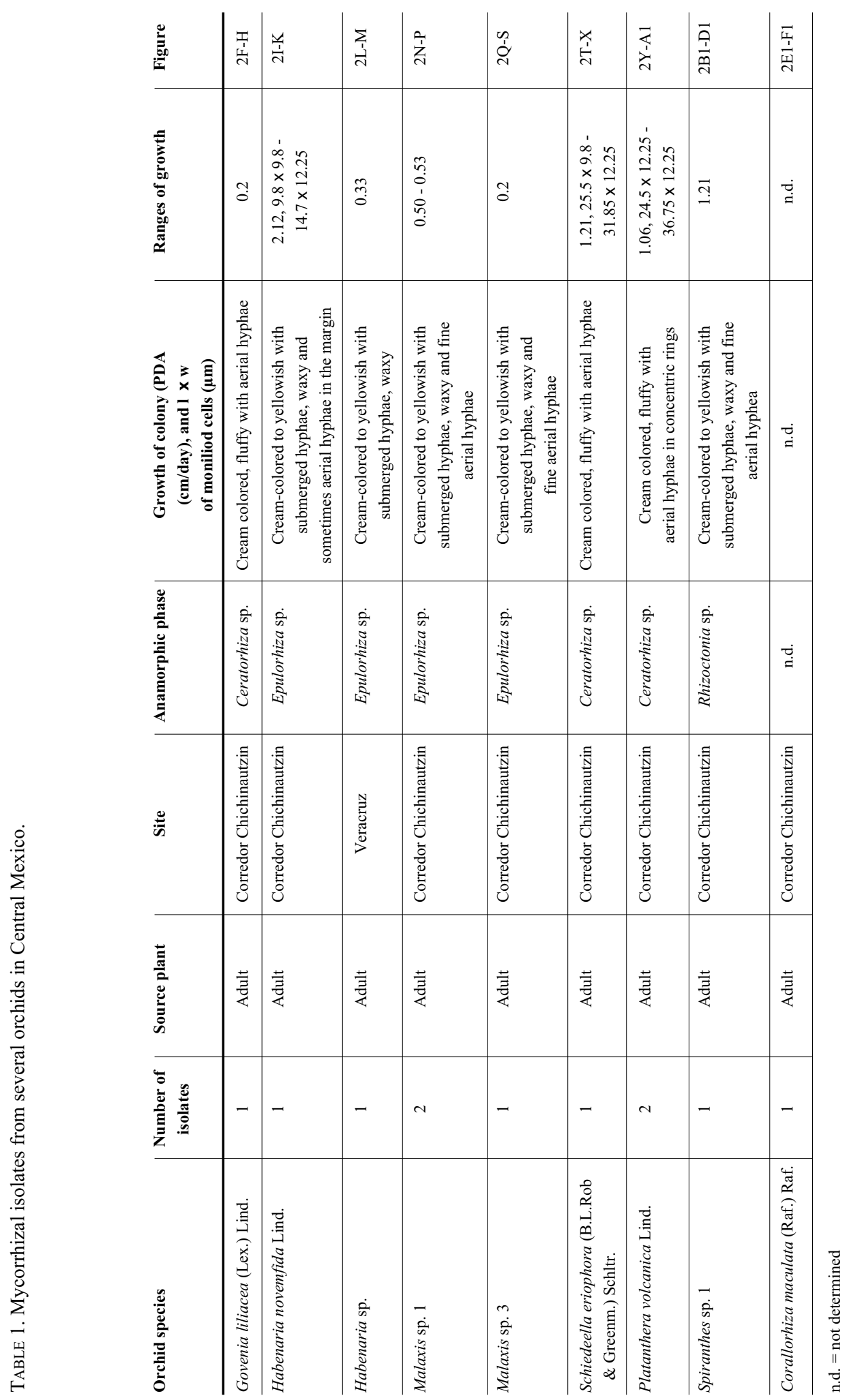




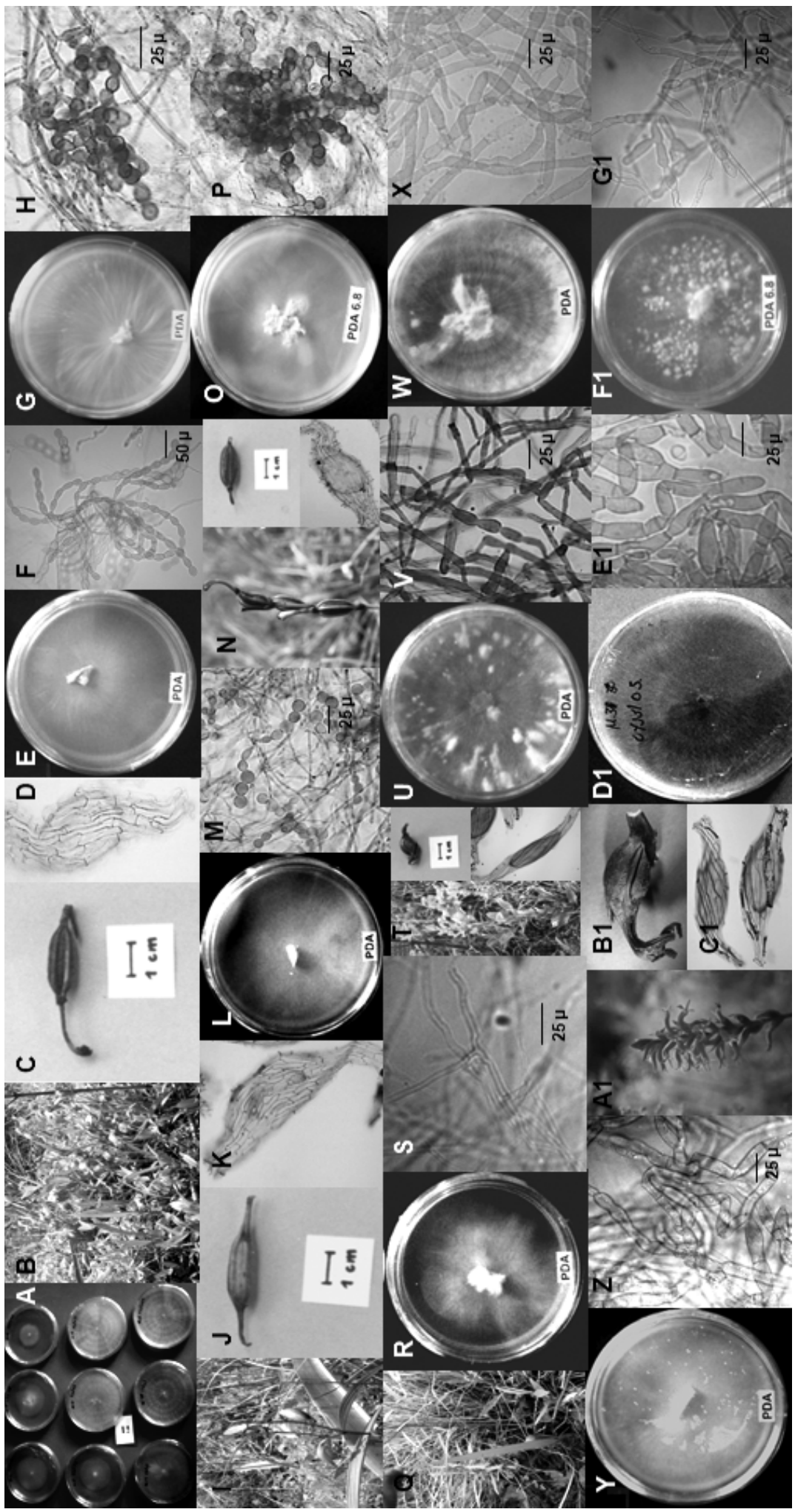

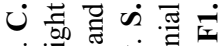

吾光

₹

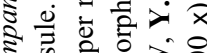

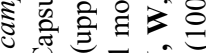

U.

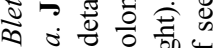

ค 50 U

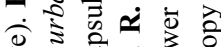

过 范

苟

$\stackrel{0}{0} 8$

के के के

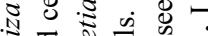

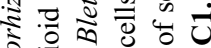

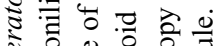

仓ั

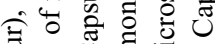

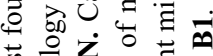

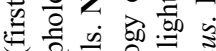

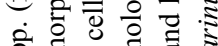

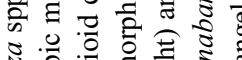

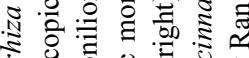

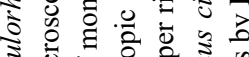

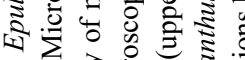

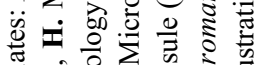

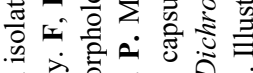

可

들

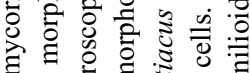

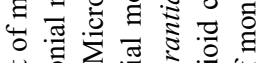

苞高交范

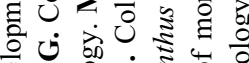

玨응 0 ह

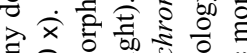

ธิ응.

8 . ज़

च छ

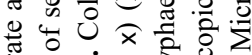

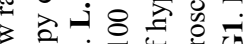

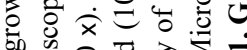

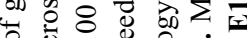

3.0

$\stackrel{0}{>}=$

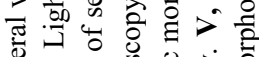

过

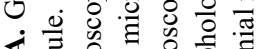

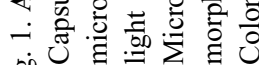

is 


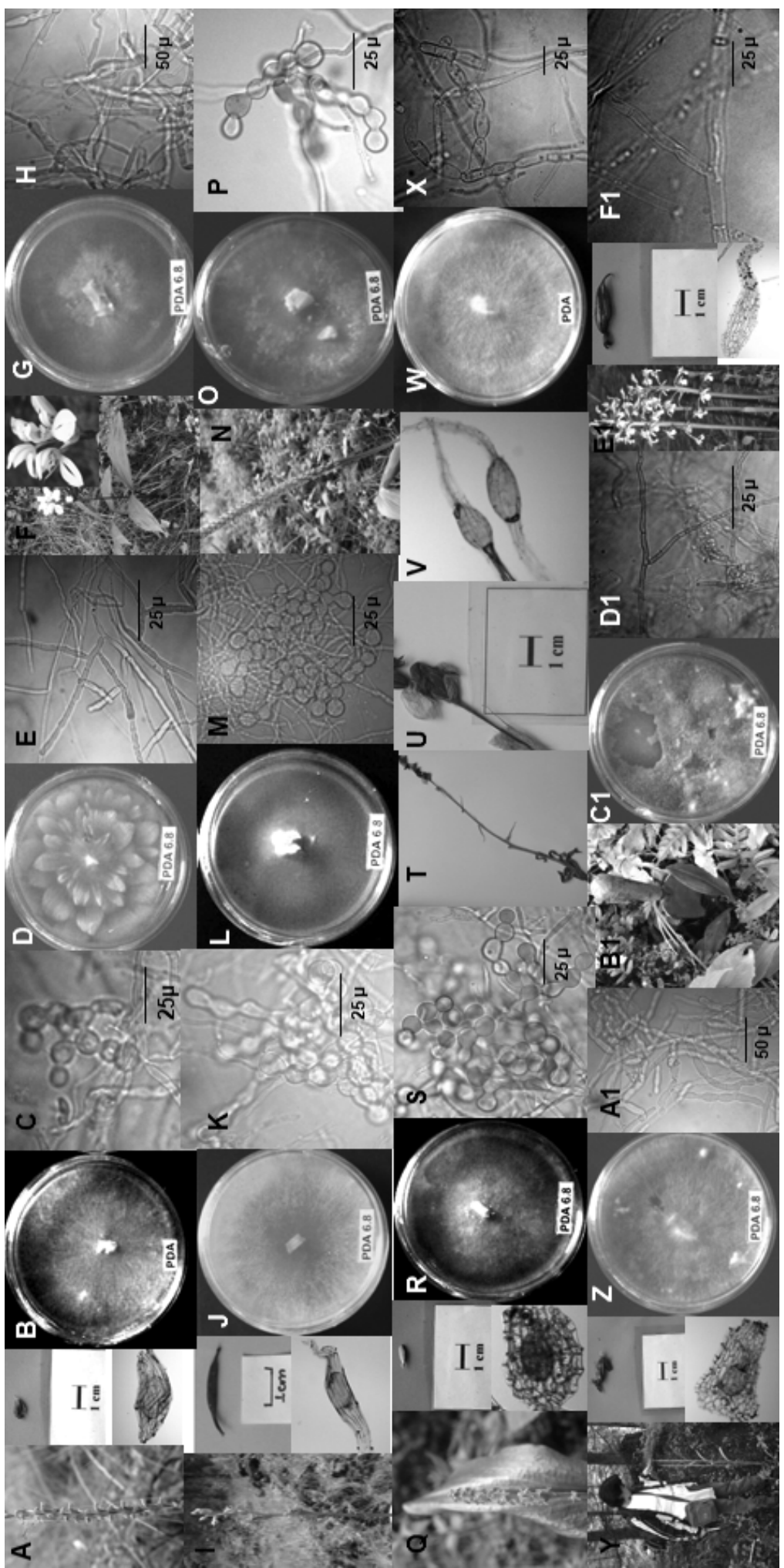

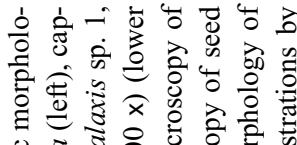

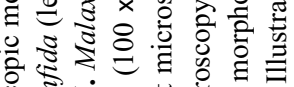

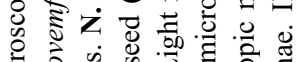

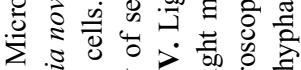

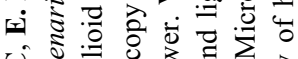

บ ठิ

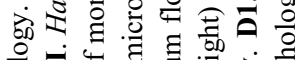

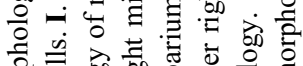

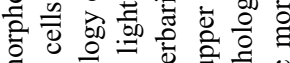

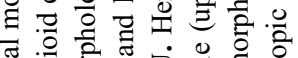

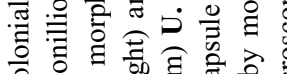

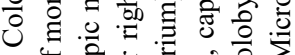
$\dot{0} 0$ oे คी को

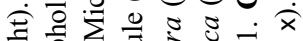
का का

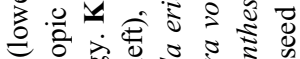
$x$ 范 ठ․ำ की च

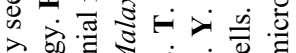
ते ن

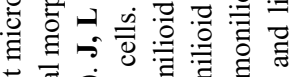

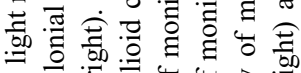

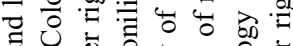
ஸ் 占 ¿ 可施

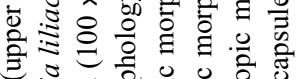

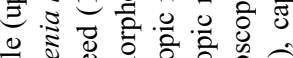
号 ठ⿱艹 दे

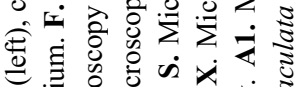

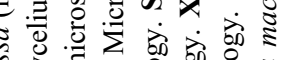
c) 8 강 든

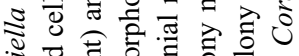

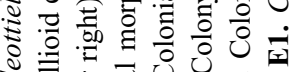

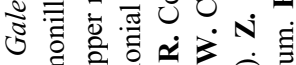

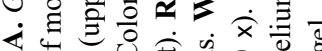
ن od is 
soil conditions and if soil seed storage has high probability to find compatible fungus partner in natural conditions.

Additional to the studies of symbiotic and asymbiotic germination in vitro and in situ, we have also conducted studies of reintroduction, in the Ecological Reserve el Pedregal (see Ortega-Larrocea and Rangel in the same volume), showing the relevance of mycorrhizal fungi in the development and survival of orchids. This is the first Mexican report that uses a combination of strategies (e.g., germplasm preservation, fungal isolation, database recording) to promote orchid conservation both in situ and ex situ. The main aim of this project is to initiate a global conservation program of symbiotic fungi diversity where a collection of seeds is necessary to test the symbiotic effectiveness of the isolates. With the reintroduction results, we intend to attire the attention of the main organisms promoting orchid conservation in Mexico and present convincing evidence that mycorrhizal fungi are necessary for any realistic conservation project. We will conduct future research to demonstrate that habitat degradation decreases the biodiversity functions of soil and fungi potential and in consequence, the ability of orchids to survive in nature. We are conscious that this will be a long-term project and at the present, we attempt only easy in vitro bioassays with the recently collected material testing seed and fungi viability, isolate effectiveness and isolate diversity and specificity.

Acknowledgements. We sincerely thank Victor Peña for field assistance and expertise and Dr. L. Zettler for encouraging our research. Financial grants were obtained for Conacyt-Jóvenes a la Investigación Project No. 45243.

\section{Literature Cited}

Cano-Santana, Z. \& J.C. Meave. 1996. Sucesión primaria en derrames volcánicos: el caso del Xitle. Ciencias 41: 58-68.

Castillo-Argüero, S., G. Montes-Cartas, M.A. RomeroRomero, Y. Martínez-Orea, P. Guadarrama-Chávez, I. Sánchez-Gallén \& O. Núñez-Castillo. 2004. Dinámica y conservación de la flora del matorral Xerófilo de la reserva del Pedregal de San Ángel (DF, México). Bol. Soc. Bot. México 74: 51-75.

Ceballos, G. \& C. Galindo. 1984. Mamíferos silvestres de la Cuenca de México. Ed. Limusa-MAB, México. 299 p.
Currah, R.S., C.D. Zelmer, S. Hambleton \& K.A. Richardson. 1997. Fungi from orchid mycorrhizas Pp. 117-170 in: J. Arditti A.M. Pridgeon (eds.), Orchid Biology: Reviews and Perspectives, VII. Kluwer Academic Publishers, Grat Britain.

Espejo, S.A., C.J. García, F.A. López, M.R. Jiménez \& S.L. Sánchez. 2002. Orquídeas del Estado de Morelos. Orquídea (Méx.) 16: 332 p.

Hágsater, E., M.A. Soto, G.A. Salazar, R. Jiménez, M.A. López \& R.L. Dressler. 2005. Las orquídeas de México. Instituto Chinoín, México, D. F. 302 p.

Herrera, A.L. \& L.L. Almeida. 1994. Relaciones fitogeográficas de la flora vascular de la reserva del Pedregal de San Ángel, México DF. Pp. 83-89 in: A. Rojo (comp.), Reserva Ecológica "El Pedregal” de San Ángel: Ecología, Historia Natural y Manejo. UNAM, México. D.F. pp 83-90.

Koopowitz, H., P.S. Lavarack \& K.W. Dixon. 2003. The nature of threats to orchid conservation. Pp. 25-42 in: K.W. Dixon, S.P. Kell, R.L. Barrett \& P.J. Cribb. Orchid conservation. Natural History Publications. Malaysia.

Mera, L.M., M.A.A. Zarate \& Y.A. Sandoval. 2002. El herbarium del pedregal de San Angel. Ciencias 67: 4243.

Rangel, V.M. 2004. Aislamiento de hongos micorrízicos de orquídeas terrestres de la Reserva "El Pedregal" de San Angel, México. D. F. Tesis de Licenciatura, Facultad de Estudios Superiores, Iztacala, Universidad Nacional Autónoma de México. 113 p.

Rangel, V. M. 2006. Germinación simbiótica y reintroducción de orquídeas terrestres en la Reserva ecológica del Pedregal de San Angel, México, México D. F. Tesis de maestría, Posgrado en Ciencias Biológicas, Universidad Nacional Autónoma de México. 115 p.

Rubluo, A., V. Chávez, A.P. Martínez \& O. MartínezVázquez. 1993. Strategies for the recovery of endangered orchids and cacti through in vitro culture. Biol. Conserv. 63: 163-169.

Rzedowski, J. 1954. Vegetación del Pedregal de San Angel (D. F. México). An. Esc. Nac. Cienc. Biol. IPN, 8: 59-129. México.

Rzedowski, J. 1991. El endemismo de la flora fanerogámica mexicana: una apreciación analítica preliminar. Acta Bot. Mex.: 47-64.

Siebe, C., V. Rodríguez-Lara, P. SCAF \& M. Abrams. 2004. Radiocarbon ages of Holocene Pelado, Guespalapa and Chichinautzin scoria cones, south of Mexico city: Implications for archaeology and future hazards. Bull. Volcanol. 66: 203-225.

Téllez-Velasco, M.A. 2002. The Pedregal of San Ángel and its orchids. Orch. Rev. 110: 25-29. 
Valiente-Banuet A. \& E. De Luna-García. 1994. Una lista florística para la reserva del Pedregal de San Ángel, México DF. Pp. 67-89 in: A. Rojo (comp.), Reserva Ecológica "El Pedregal" de San Ángel: Ecología, Historia Natural y Manejo. UNAM, México, D.F.

Vázquez, L. 1973. Estudios sobre algunos aspectos taxonómicos y ecológicos de insectos del Pedregal de San Angel, México D. F. Folia Entomol. 25-6: 102-104.
Wotavová, K., Z. Balounová \& P. Kindlmann. 2004. Factors affecting persistence of terrestrial orchids in wet meadows and implications for their conservation in a changing agricultural landscape. Biol. Conserv. 118: 271-279.

Zettler LW. 1997. Terrestrial orchid conservation by symbiotic seed germination: Techniques and perspectives. Selbyana 18(2): 188-194.

Mónica Rangel, Master in Science graduated at the Universidad Nacional Autónoma de México in 2006. She is interested in the conservation of terrestrial orchids using symbiotic propagation and reintroduction into their natural habitat and the identification of mycorrhizal fungi.

Pilar Ortega is Associated Professor at the Universidad National Autónoma de Mexico where she works as a researcher in the Instituto de Geología. She is interested in the association with mycorrhizal fungi in orchids and other plants, particularly arbuscular mycorrhizal fungi. She starts the direction of some students to develop a research project of orchid mycorrhizal fungi in Mexico and she is pioneer on this matter in this country. 